\title{
EFEKTIVITAS MODUL ELEKTRONIK BERBASIS SAINTIFIK PADA MATERI KELARUTAN DAN HASIL KALI KELARUTAN UNTUK MENINGKATKAN KETERAMPILAN PROSES SAINS SISWA SMA
}

\author{
Bayu Antrakusuma ${ }^{1)}$, Mohammad Masykuriं ${ }^{2}$, Maria Ulfa ${ }^{3)}$, Isma Aziz Fakhrudin ${ }^{4)}$, Icha \\ Kurnia Wati ${ }^{5)}$, Annisa Nur Khasanah ${ }^{6)}$ dan Meida Wulan Sari ${ }^{7}$ \\ 1,4,5,6,7 Dosen Prodi Pendidikan IPA, Universitas Sebelas Maret \\ ${ }^{2,3}$ Dosen Prodi Pendidikan Kimia, Universitas Sebelas Maret \\ E-mail: antrakusumabayu@staff.uns.ac.id
}

Diajukan: 9 January 2021; Diterima: 20 February 2021; Diterbitkan: 30 April 2021

\begin{abstract}
Abstrak: Penelitian ini bertujuan untuk mengetahui keefektivitasan modul elektronik berbasis saintifik pada materi kelarutan dan hasil kali kelarutan untuk meningkatkan keterampilan proses sains siswa SMA. Penelitian keefektifan modul elektronik berbasis saintifik ini didahului dengan penelitian pengembangan (RnD) terlebih dahulu dengan jenis penelitian yang digunakan yaitu model pengembangan media yang mengacu pada teori Borg dan Gall dengan langkah-langkah yaitu, 1) penelitian dan mengumpulkan informasi, 2) merencanakan, 3) mengembangkan bentuk awal produk, 4) uji lapangan awal, 5) Rrevisi produk utama, 6) uji lapangan utama, 7) revisi produk operasional, 8) uji lapangan operasional, 9) revisi produk akhir, dan 10) diseminasi. Uji efektifitas produk modul elektronik dilaksanakan pada bagian revisi produk akhir. Sumber data pada penelitian ini berasal dari siswa SMAN 1 Teras. Subjek penelitian yang digunakan adalah 68 siswa dengan rincian masing-maing 34 siswa dari kelas XI MIA 2 dan XI MIA 3.Teknik penelitian yang digunakan adalah observasi. Observasi keterampilan proses sains dilakukan oleh tiga observer. Teknik analisis data yang digunakan adalah analisis deskriptif kualitatif dan kuantitatif. Hasil uji statistik menunjukkan ada perbedaaan nilai keterampilan proses sains (KSP) antara kelas kontrol dan eksperimen sehingga modul elektonik berbasis sainstifik ini efektif digunakan dalam pembelajaran guna memberdayakan keterampilan proses sains siswa.
\end{abstract}

Kata Kunci: Modul elektronik, sainstifik, keterampilan proses sains, kelarutan dan hasil kali kelarutan

\begin{abstract}
This study aims to determine the effectiveness of scientific-based electronic modules on solubility and solubility product materials to improve science process skills of high school students. Research on the effectiveness of this scientifically based electronic module was preceded by development research (RnD) first with the type of research used, namely the media development model that refers to the Borg and Gall theory with steps, namely, 1) research and collecting information, 2) planning, 3 ) developing the initial form of the product, 4) initial field test, 5) main product revision, 6) main field test, 7) operational product revision, 8) operational field test, 9) final product revision, and 10) dissemination. The test of the effectiveness of the electronic module product is carried out in the revision of the final product. Sources of data in this study came from students of SMAN 1 Teras. The research subjects used were 68 students with details of 34 students from class XI MIA 2 and XI MIA 3. The research technique used was observation. Observations of science process skills were carried out by three observers. The data analysis technique used is descriptive qualitative and quantitative analysis. The results of the statistical test showed that there was a difference in the value of science process skills (KSP) between the control and experimental classes so that this scientifically based electronic module was effectively used in learning to empower students' science process skills.
\end{abstract}

Keywords: Electronic module, scientific, science process skills, solubility and solubility product

\section{Pendahuluan}

Perkembangan teknologi di era globalisasi saat ini bisa dibilang telah merubah kehidupan menjadi peradapan yang lebih maju bahkan perkembangan teknologi dapat mencakup hampir semua bidang kehidupan. Teknolgi yang semakin maju berdampak pada perubahan sikap pada masyarakat. Kini masyarakat tidak dapat lepas dan sangat bergantung pada perkembangan teknologi tersebut karena pada hakikatnya manusia akan selalu mengikuti dan menyesuaikan diri dengan perubahan yang terjadi pada kehidupannya (Van Deursen, 2015). Oleh karena itu alangkah lebih baik apabila kita dapat menerapkan perkembangan teknologi 
guna meningkatkan efektifitas kita dalam menjalani kehidupan sehari-hari, salah satunya adalah memanfaatkan teknologi dalam bidang pendidikan.

Pendidikan di Indonesia saat ini juga telah berubah mengikuti perkembangan zaman. Kurikulum 2013 yang diterapkan saat ini merupakan kurikulum terbaru yang di dalamnya terdapat penyempurnaan dari kurikulum sebelumnya. Kurikulum 2013 menekankan kepada pola pembelajaran yang berpusat pada siswa dengan pendekatan saintifik sehingga siswa diharapkan aktif dalam kelas mencari solusi dari permasalahan pembelajaran dengan cara berkelompok dan memanfaatkan media belajar yang mendukung.

Kimia merupakan ilmu yang mencakup tiga level representasi, yaitu level makroskopik, level mikroskopik, dan level simbolik (Johnstone, 1991). Salah satu materi pelajaran kimia yang mencakup tiga level representasi adalah materi pokok kelarutan dan hasil kali kelarutan. Level makroskopik, misalnya garam perak klorida yang memiliki kelarutan rendah akan sukar larut dalam air sehingga dapat dilihat oleh mata. Level mikroskopik, di dalam fenomena endapan dalam kelarutan perak klorida tersebut terjadi reaksi kesetimbangan antara ion perak dan ion klorida menjadi padatan perak klorida. Hal ini tidak dapat diamati langsung oleh mata. Level simbolik, reaksi kesetimbangan garam perak klorida tersebut dan dilihat dengan merubahnya menjadi simbol $(\mathrm{AgCl}(\mathrm{s}) \rightleftarrows$ $\left.\mathrm{Ag}^{+}(\mathrm{aq})+\mathrm{Cl}^{-}(\mathrm{aq})\right)$. Materi ini juga bersifat abstrak. Hal tersebut tidak bisa dilihat dengan kasat mata dan hanya bisa dilakukan dengan pengandaian dan permisalan sehingga apabila diterapkan media elektronik yang dapat mengvisualkan hal tersebut akan membantu siswa dalam memahami materi kelarutan dan hasil kali kelarutan.

Keterampilan Proses Sains (KPS) merupakan kemampuan siswa untuk menerapkan metode ilmiah dalam memahami, mengembangkan, dan menemukan ilmu pengetahuan (Dahar, 2011). Lebih lanjut KPS merupakan keterampilan khusus yang menyederhanakan ilmu belajar, mengaktifkan siswa, mengembangkan rasa tanggung jawab dalam pembelajaran mereka sendiri, mingkatkan ketetapan pembelajaran, serta mengajari mereka metode penelitian (Karamustafaoğlu, 2011). KPS sangat penting bagi siswa sebagai bekal untuk mengembangkan sains dengan memanfatkan metode ilmiah guna memperoleh keilmuan baru. Menurut Guritno (2015) fakta di sekolah dalam pembelajaran kimia, banyak siswa hanya mempelajari konsep-konsep dan prinsip-prinsip sains secara verbalistik atau siswa belajar tetapi tidak mengetahui makna dari yang dipelajarinya secara jelas.

Berdasarkan hasil observasi dan wawancara didapatkan hasil SMAN 1 Teras menggunakan Kurikulum 2013. Penerapan pembelajaran kimia di sekolah masih didominasi oleh guru. Guru memanfaatkan buku pedoman atau buku cetak mata pelajaran kimia dalam mengajar. Namun kendala yang didapatkan dalam memanfaatnkan buku ajar tersebut adalah kurangnya visualisasi yang memudahkan siswa dalam memahami materi. Pembelajaran kimia akan menjadi kurang efektif dikarenakan guru lemah dalam mengaplikasikan atau menggambar subyek abstrak dari kimia (Holbrook, 2015).

Berdasarkan hasil wawancara bersama guru kimia kelas XI SMAN 1 Teras mengatakan bahwa buku cetak yang digunakan dalam mengajar bisa apa saja karena semua materi kimia di semua buku hampir sama. Hal ini menunjukkan bahwa belum ada perhatian terhadap media yang menerapkan pendekatan khusus seperti saintifik didalamnya. Keberadaan buku cetak yang berbasis Kurikulum 2013 belum menjadi pilihan utama sehingga dalam penyajian materi masih belum bisa memancing siswa dalam meningkatkan Keterampilan Proses Sains. Guru terkadang menyampaikan materi dengan media power point, namun media tersebut masih tergolong sederhana dan kurang ineraktif begitu pula dengan kegiatan di laboratorium karena keterbatasan waktu sehingga pemanfaatannya kurang maksimal.

Berdasarkan permasalahan tersebut maka dikembangkan suatu modul elektronik berbasis pendekatan saintifik untuk meningkatkan keterampilan proses sains siswa pada materi kimia yaitu kelarutan dan hasil kali kelarutan. Modul elektronik ini dapat menjadi salah satu alternatif bagi guru dalam menerapkan kegiatan pembelajaran berbasis saintifik sehingga dengan memanfaatkan 
media elektronik ini diharapkan dapat memberdayakan keterampilan proses sains siswa.

\section{Metode Penelitian}

Penelitian keefektifan modul elektronik berbasis saintifik ini didahului dengan penelitian pengembangan ( $\mathrm{RnD})$ terlebih dahulu dengan jenis penelitian yang digunakan yaitu model pengembangan media yang mengacu pada teori Borg dan Gall dengan langkah-langkah yaitu, 1) penelitian dan mengumpulkan informasi, 2) merencanakan, 3) mengembangkan bentuk awal produk, 4) uji lapangan awal, 5) Rrevisi produk utama, 6) uji lapangan utama, 7) revisi produk operasional, 8) uji lapangan operasional, 9) revisi produk, dan 10) diseminasi. Penelitian ini dibatasi pada tahap kesembilan yaitu revisi produk. Observasi keterampilan proses sains untuk uji efektifitas produk modul elektronik dilaksanakan pada bagian revisi produk akhir.

Penelitian pengembangan ini dilaksanakan di SMAN 1 Teras. Kelas yang digunakan adalah kelas XI MIA 2 sebagai kelas kontrol dan kelas XI MIA 3 sebagai kelas eksperimen. Kelas yang digunakan telah memenuhi uji prasyarat terhadap nilai ulangan siswa pada materi kimia sebelumnya, diantaranya adalah uji homogenitas dengan nilai signifikasi 0,97 atau $>0,05$ yang berarti data telah homogen, uji normalitas dengan nilai signifikasi 0,00 atau $<0,05$ yang berarti data tidak berdistribusi normal, dan uji t-matching dengan nilai signifikasi 0,75 atau >0,05 yang berarti kedua kelas tidak memiliki perbedaan rata-rata nilai. Analisis prasyarat ini memanfaatkan software IMB SPSS.

Subjek penelitian yang digunakan adalah 68 siswa dengan rincian masing-maing 34 siswa dari kelas XI MIA 2 dan XI MIA 3. Teknik penelitian yang digunakan adalah obeservasi. Instrumen yang digunakan adalah lembar observas. Observasi keterampilan proses sains dilakukan oleh tiga observer. Teknik analisis data yang digunakan dalam penelitian ini adalah analisis deskriptif kuantitatif dan kualitatif, yaitu dengan mendeskripsikan dan memaknai data yang bersifat kuantitatif maupun kualitatif.

Hasil keterampila proses sains tampak dalam bentuk skill dan kemampuan individu dalam menjalani sains di kelas. Analisis penelitian keterampilan ini dilakukan untuk mengetahui ketuntasan belajar pada kegiatan saintifik. Rumus yang digunakan untuk menganalisis skor yang diperoleh yaitu:

$$
\text { Nilai KPS }=\frac{\text { skor yang diperoleh }}{\text { skor maksimal }} \times 100
$$

Cara untuk menentukan kategori hasil keterampilan proses sains siswa digunakan pedoman yang disesuaikan pada permendikbud nomor 104 Tahun 2014 sebagaimana tertera pada Tabel 1.

Tabel 1 Kriteria Penilaian Keterampilan Proses Sains (KSP) menurut Permendikbud No. 104 Tahun 2014

\begin{tabular}{cc}
\hline Capaian Optimum & Huruf \\
\hline $3,85-4,00$ & $\mathrm{~A}$ \\
$3,51-3,84$ & $\mathrm{~A}-$ \\
$3,18-3,50$ & $\mathrm{~B}+$ \\
$2,85-3,17$ & $\mathrm{~B}$ \\
$2,51-2,84$ & $\mathrm{~B}-$ \\
$2,18-2,50$ & $\mathrm{C}+$ \\
$1,85-2,17$ & $\mathrm{C}$ \\
$1,51-1,84$ & $\mathrm{C}-$ \\
$1,18-1,50$ & $\mathrm{D}+$ \\
$1,00-1,17$ & $\mathrm{D}$ \\
\hline
\end{tabular}

\section{Hasil Penelitian dan Pembahasan}

Pembelajaran dilakukan selama lima kali pertemuan disetiap kelasnya, yaitu empat kali pertemuan pembelajaran dan satu kali pertemuan untuk evaluasi pembelajaran. Selama pembelajaran berlangsung, peneliti mengobservasi keterampilan proses sains siswa.

Observasi dilakukan setiap hari selama pertemuan pembelajaran. Pertemuan terakhir merupakan pertemuan untuk mengevaluasi siswa mengenai pembelajaran yang telah didapatkan melalui soal/instrumen evaluasi pengetahuan. Selain itu, dilakukan evaluasi sikap sosial siswa mengunakan angket teman sejawat.

Selama penerapan modul elektronik berbasis saintifik, siswa dibagi menjadi lima kelompok dan difasilitasi modul elektronik (bagi kelas eksperimen) berisi materi kelarutan dan hasil kali kelarutan yang telah disesuaikan dengan pendekatan saintifik serta fasilitasi dengan animasi interaktif. Hal ini didasari oleh teori Vygotsky bahwa pembelajaran dengan pendekatan saintifik adalah kemampuan untuk 
mewujudkan tatanan pembelajaran kooperatif dengan dibentuk kelompok-kelompok belajar yang mempunai tingkat kemampuan berbeda dan penekanan perancahan dalam pembelajaran supaya siswa mempunya tanggungjawab terhadap belajar. Berkelompok juga efektif diterapkan dalam pembelajaran kelas karena dalam melakukan penemuan dibutuhkan beberapa kontribusi siswa lain agar pembelajaran dapat berjalan dengan baik.

Hasil observasi keterampilan proses sains siswa untuk kelas kontrol dan eksperimen pada pertemuan pertama berturutturut adalah 55,05\% dan 65,20\%. Berdasarkan hasil ini dapat disimpulkan bahwa kelas yang menggunakan modul memiliki KPS yang lebih tinggi. Namun persentase ketercapaiannya masih rendah. Hal ini dikarenakan siswa belum terbiasa dengan metode dan media pembelajaran yang diterapkan. Begitu pula pada pertemuan kedua. Meskipun masih rendah namun persentase ketercapaian KPS pada kelas kontrol dan eksperimen meningkat, yaitu dari $55,05 \%$ menjadi $64,71 \%$ dan $65,20 \%$ menjadi $65,88 \%$. Hal ini dapat disimpulkan bahwa tiap kelas sudah mulai terbiasa dengan metode dan media yang diterapkan. Terdapat peningkatan yang cukup sigifikan pada kelas kontrol maupun kelas eksperimen pada pertemuan ke tiga dan ke empat terlihat. Persentase ketercapaian KPS kelas kontrol dan eksperimen pada pertemuan ke tiga dan keempat didapatkan berturut-turut adalah $67,25 \%$ menjadi $77,60 \%$ dan $74,31 \%$ menjadi $85,78 \%$. Hal ini diakibatkan mulai terbiasanya siswa terhadap metode dan media yang diterapkan.

Kelas eksperimen memiliki persentase KPS yang lebih tinggi dikarenakan siswa secara aktif mengikuti pembelajaran berbasis saintifik. Selain itu siswa telah memanfaatkan modul elektronik yang diberikan sehingga secara tidak langsung siswa dibimbing untuk melaksanakan kegiatan yang memunculkan keterampilan proses sains. Setiap langkahlangkah yang terdapat pada modul elektronik ini secara spesifik mendorong siswa untuk aktif dan memberdayakan keterampilan proses sainsnya (memprediksi, mengumpulkan data, menyiapkan percobaan, menyimpulkan, dan mengomunikasikan) di dalam pembelajaran. Oleh karena itu kelas yang memanfaatkan modul elektronik berbasis saintifik ini akan memiliki keterampilan proses sains yang lebih baik.

Selain data ketercapaian KPS setiap pertemuan, disajikan juga data ketercapaian indikator KPS setiap kelas. Berdasarkan observasi, didapatkan bahwa kelas eksperimen memiliki ketuntasan KPS lebih tinggi dibanding kelas kontrol di tiga indikatornya, yaitu "merencanakan percobaan" dengan persentase kelas kontrol dan eksperimen berturut turut adalah $49,63 \%$ dan $73,10 \%$. Hal ini dikarenakan modul elektronik memungkinkan siswa untuk melakukan eksperimen laboratorium virtual setiap harinya, sehingga indikator KPS ini dapat muncul dan diukur. Sedangkan di kelas kontrol, pembelajaran eksperimen laboratorium hanya dilakukan satu kali pada pertemuan akhir sehingga keterampilan ini tidak muncul secara maksimal. Indikator "mengumpulkan data" dengan persentase kelas kontrol dan eksperimen berturut-turut adalah $62,13 \%$ dan $70,77 \%$. Siswa pada kelas eksperimen melakukan percobaan laboratorium virtual sehingga memungkinkan mencatat data yang didapat secara tepat. Indikator "mengomunikasikan" dengan persentase kelas kontrol dan eksperimen berturut-turut adalah $67,95 \%$ dan $75,49 \%$. Hal ini membuktikan bahwa adanya peran modul elektronik berbasis saintifik dalam memunculkan keterampilan proses sains pada kelas eksperimen. Namun, untuk indikator "memprediksi" hampir tidak memiliki perbedaan persentase antara kelas kontrol dan eksperimen, yaitu $70,77 \%$ dan $70,65 \%$. Hal ini dimungkinkan modul elektronik ini tidak begitu berpengaruh terhadap keterampilan siswa dalam memprediksi. Pada indikator "menyimpulkan" ternyata kelas kontrol memiliki persentase lebih besar dibanding kelas eksperimen, yaitu berturut-turut adalah $80,27 \%$ dan $73,96 \%$. Hal ini dapat disimpulkan keterampilan dalam menyimpulkan pembelajaran dapat muncul meskipun tanpa diberikan modul elektronik.

Berdasarkan data diatas, dapat disimpulkan bahwa modul elektronik berbasis saintifik ini hanya efektif meningkatkan tiga indikator proses sains saja (menyiapkan percobaan, mengumpulkan data, dan mengomunikasikan). Namun, kelas yang diterapkan modul elektronik masih memiliki rata-rata ketuntasan yang lebih baik dari pada 
kelas kontrol. Nilai rata-rata ketuntasan keterampilan proses sains siswa kelas kontrol dan eksperimen berturut-turut adalah $66,15 \%$ (kategori B-) dan 72,79\% (kategori B).

Kelas eksperimen memiliki nilai persentase optimum yang lebih tinggi dibandingkan kelas kontrol. Hal ini sesuai dengan penelitian yang dilakukan oleh Sukarno (2014) bahwa penerapan simulasi komputer interaktif dalam pembelajaran menjadi rekomendasi bagi para guru guna meningkatkan kemampuan proses sains di pembelajaran. Didukung juga oleh penelitian Osman dan Vebrianto (2013) serta Pekdağ (2010) yang membahas tentang metode alternatif untuk membelajarkan kimia menggunakan ICT dilengkapi animasi, simulasi, video dan multimedia lainnya yang efektif diterapkan dalam pembelajaran guna meningkatkan keterampilan proses sains.

Efektivitas modul elektronik berbasis saintifik ini dapat diketahui melalui uji statistik menggunakan software IMB SPSS. Namun, sebelumnya diperlukan uji prasyarat yaitu uji normalitas, dan homogenitas terhadap nilai keterampilan proses sains tersebut. Data yang digunakan untuk uji statistik adalah nilai ratarata dari pertemuan 3 dan 4 saja, hal ini dikarenakan pertemuan 1 dan 2 dianggap belum maksimal dalam penerapan modul dan metode.

Hasil uji normalitas melalui SPSS didapatkan nilai signifikansi menurut ShapiroWilk yaitu kelas kontrol adalah 0,09>0,05 sehingga Ho (data berdistribusi normal) diterima. Dapat disimpulkan bahwa kelas kontrol memiliki data berdistribusi normal, sedangkan kelas eksperimen mendapatkan nilai signifikansi $0,01<0,05$ sehingga Ho ditolak. Dapat disimpulkan bahwa data pada kelas eksperimen tidak berdistribusi normal. Uji prasyarat berikutnya adalah uji homogenitas, menggunakan uji Levene. Hasil uji homogenitas yaitu didapatkan nilai signifikansi yang diperoleh oleh kedua kelas adalah 0,24>0,05 sehingga Ho (Data homogen) diterima. Dapat disimpulkan data kelas merupakan data yang homogen. Dikarenakan terdapat data yang tidak normal pada kelas eksperimen, meskipun data telah homogen, untuk uji perbedaan rata-rata nilai keterampilan proses sains setiap kelas menggunakan uji nonparametrik (Mann Whitney). Berdasarkan uji Mann Whitney melalui SPSS, dapat dilihat bahwa nilai signifikansi $0,00<0,05$ sehingga Ho (tidak terdapat perbedaan nilai KPS siswa) ditolak. Hal ini dapat disimpulkan terdapat perbedaan nilai keterampilan proses sains yang signifikan antara kelas ekperimen (menggunakan modul elektronik berbasis saintifik) dan kelas kontrol (menggunakan modul elektronik berbasis saintifik).

Berdasarkan hasil penelitian, terliat bahwa pembelajaran menggunakan modul elektronik berbasis saintifik mampu memberdayakan keterampilan proses sains secara efektif. Hal ini sesuai denan penelitian yang dilakukan oleh Zeidan dan Jayosi (2015) yang membahas tentang pembentukan attitude dan keterampilan proses sains melalui sekolah yang menerapkan saintifik dalam pembelajaran. Didukung oleh penelitian Feyzioglu (2009), yang menyebutkan bahwa pembelajaran saintifik memanfaatkan percobaan laboratorium didalamnya efektif diterapkan untuk memberdayakan keterampilan proses sains. Atas dasar hasil uji efektivitas produk yang telah dilakukan diatas serta mempertimbangkan penelitian terkait, dapat disimpulkan bahwa modul elektronik berbasis saintifik ini efektif untuk memberdayakan dan meningkatkan keterampilan proses sains siswa.

\section{Kesimpulan dan Rekomendasi}

Berdasarkan hasil penelitian dan pembahasan dapat disarankan sebagai berikut:

1. Saran bagi Guru

a. Sebaiknya guru memahami dan telah menerapkan pendekatan saintifik di kelas dengan baik

b. Modul elektronik berbasis saintifik ini dapat dijadikan contoh untuk memotivasi guru dalam meningkatkan kreatifitas dalam menginovasi pembelajaran.

c. Modul elektronik berbasis saintifik ini dapat dikembangkan kembali untuk materi pembelajaran lainnya.

2. Saran bagi peneliti lain, hasil dari penelitian dan pengembangan ini dapat dijadikan acuan bagi penelitian sejenis lainnya dengan konteks yang berbeda

\section{Daftar Pustaka}

Dahar, R.W. 2011. Teori-teori Belajar dan Pembelajaran. Yogyakarta: Erlangga. 
Feyzioglu, B. 2009. "An Investigation of the Relationship between Science Process Skills with Efficient Laboratory Use and Science Achievement in Chemistry Education.” Turkish Science Education 6(3): 114-32.

Guritno, T.A., Masykuri,M., dan Ashadi. 2015. "Pembelajaran Kimia Melalui Model Pemecahan Masalah dan Inquri Terbimbing Ditinjau dari Keterampilan Proses Sains (KPS) Dasar dan Sikap Ilmiah Siswa." Jurnal Inkuiri 4(2): 1-9.

Holbrook, J. 2005. "Making Chemistry Teaching Relevant." Chemical Education International 6(1): 3-8.

Johnstone, A. H. 1991. "Why Is Science Difficult to Learn? Things Are Seldom What They Seem." Journal of Computer Assisted Learning 7(2): 75-83.

Karamustafaoğlu, S. 2011. "Improving the Science Process Skills Ability of Science Student Teachers Using I Diagrams." Eurasian J. Physic. Chem. Education 3(1): 26-38. http://www.eurasianjournals.com/index. php/ejpce.

Kemendikbud. 2014. Permendikbud RI Nomor 104 Tahun 2014 Tentang Penilaian Hasil Belajar oleh Pendidik pada Pendidikan Dasar dan Pendidikan Menengah.

Osman, K., dan Vebrianto, R. 2013. "Fostering Science Process Skills and Improving Achievement through the Use of Multiple Media." Journal of Baltic Science Education 12(2): 191204.

Pekdağ, B. 2010. "Alternative Methods in Learning Chemistry: Learning with Animation, Simulation, Video and Multimedia." Journal of Turkish Science Education 7(2): 111-18. http://www.tused.org/internet/tused/arch ive/v7/i2/text/tusedv7i2a5.pdf.
Sukarno, S. 2014. "Improving Science Process Skills (SPS) Science Concepts Mastery (SCM) Prospective Student Teachers Through Inquiry Learning Instruction Model by Using Interactive Computer Simulation." International Journal of Science and Research (IJSR)3(2): 6-9.

Van Deursen, Alexander J.A.M., Colin L. B, Sabrina M. H, dan Piet A.M. K. 2015. "Modeling Habitual and Addictive Smartphone Behavior: The Role of Smartphone Usage Types, Emotional Intelligence, Social Stress, SelfRegulation, Age, and Gender." Computers in Human Behavior 45: 411-20.

Zeidan, A. H. and Jayosi, M. R. 2015. "Science Process Skills and Attitudes toward Science among Palestinian Secondary School Students." World Journal of Education 5(1): 13-24. https://files.eric.ed.gov/fulltext/EJ11584 60.pdf. 